\title{
Sciendo
}

\section{The evolution of Romanian agribusiness in the context of sustainable development of agriculture}

\author{
Ioana PANAIT \\ Bucharest University of Economic Studies, Bucharest, Romania \\ Panaitioana48@gmail.com \\ Catalin Marian CUCU \\ Bucharest University of Economic Studies, Bucharest, Romania \\ Cmc.catalin02@gmail.com
}

\begin{abstract}
The agricultural competitiveness of the market depends to a large extent on the sustainable development activities that can lead to the improvement of the knowledge and professional competence of all the stakeholders from agribusiness and the Romanian agricultural sector is in an excellent position to help achieve the objectives of a smart, sustainable and inclusive economy which will allow an increased social cohesion, working together will also ensure the protection of the natural environment. Agriculture and the concept of sustainable development have received special attention due to their importance in the development of humanity as well as the impact of the phenomenon of globalization on its. Currently, there are numerous scientific studies, digital platforms for monitoring specific indicators in countries, as well as strategies and objectives at community and global level on these two-priority domains, all these inputs contributing to their improvement and innovation. Starting from the question whether the Romanian agribusiness contributes to the sustainable development of the agricultural sector, in order to carry out this research, within the methodology economic modelling was used, starting from the current situation of the Romanian agribusiness where official data and statistics were presented and analysed, as well as potential values of the main indicators needed for the transition of agriculture towards a sustainable development. The paper demonstrates that for the sustainability of the agriculture sector, an integrated approach is needed which consists in applying ecological and socio-economic concepts in the management and strategies of agribusiness. The paper contributes to the creation of a future image achieving sustainability of agriculture where the Romanian agribusiness sector must be managed from a holistic perspective based on a synergy with the elements of sustainable development.
\end{abstract}

Keywords: Sustainable development, Agriculture sector, Innovation, Inclusive businesses, Competitiveness.

\section{Introduction}

Modern society is increasingly demanding efficient and sustainable production in a global society. The competitiveness is now focused on competitors who choose to differentiate themselves by adopting sustainable practices thus having a major competitive advantage, the new demands of consumers and their concerns about health, animal welfare and environmental protection, lowcarbon economy, determine today's farmer to keep up with the world in continuous change, to adapt and manage to carry out its activity (Pjanic et al., 2018).

Starting from the question how sustainable development of agriculture influence the agribusiness sector from Romania, we analysed part of statistic data about the evolution of the principle indicators of financial development, but also agriculture indicators to reflect the dimension and the principle characterization of its.

The agricultural competitiveness on the world market depends largely on the research and development and innovation activities that can lead to the improvement of the knowledge and 
professional competence of all parties involved. Despite a global market and a competition that uses the technologies present in the agrofood chain, agricultural production in Romania is part of the legacy of local traditions and flavours the preservation of beautiful landscapes throughout Europe.

The method of practicing agriculture and managing agricultural systems offers a vital contribution to the conservation of the environment and the development of the rural area. Sustainable agriculture gives farmers the opportunity to earn a higher income, provides consumers with food safely and leads to the conservation of the natural environment. Investing in agriculture is one of the most efficient methods of developing the rural economy, improving food security and reducing malnutrition and the investments for agribusiness especially for modernization of agricultural sector, would bring considerable improvements to these essential elements that contribute to the sustainability of the agriculture.

We live in a world that is facing major environmental challenges, including climate change and depletion of natural resources, but also a world where future food production must meet global demand.

\section{Literature review}

The sustainable development concept is based on fairness and balance between economic growth and human development by improving living conditions, all activities being in harmony with the natural environment, taking into account simultaneously the 3 specific pillars of sustainable development: social, economic and environment (Soubbotina, 2004). The goal of sustainable development is to create and maintain long-term systems that combine at the same time socioeconomic prosperity and environmental protection. (Folke et. al., 2002)

Sustainable development wants to ensure that current needs are met without wasting the resources needed for the next generation, given the long-term progress for world, by continuously improving the aspects of socio-economic pillars while protecting the environment. Currently, sustainable development is a holistic viewpoint concept used in long-term strategies. (Tomislav, 2018).

The first sign that the economic and social evolutions of nations and of all mankind can no longer be separated from the effects of human activity on the natural environment were made at the United Nations Environment Conference in 1972, when nations express their concern about how human activity influences the environment.

The problems of pollution, the destruction of non-renewable natural resources, the deterioration of the natural environment, the danger of the disappearance of species and the need to increase the standard of living of the population are underlined also the connection between the quality of life of people and the quality of the natural environment for present and future generations is inseparable, the evolution of five factors (population growth, the harmful impact of intensive industrialization, multiple negative effects of pollution, food production and depletion of natural resources) suggesting that the development model practiced at that time cannot be sustained in the long term ( United Nations, 1973).

Sustainable development must be an integral part of agribusiness by modelling supply chains with an emphasis on the three pillars of sustainability - social, economic and environment offering concrete actions with viable solutions. The Food and Agriculture Organization (FAO) defined in 1988 the development of sustainable agriculture as "the management and conservation of the base of natural resources and the orientation of these changes, to ensure the continuous satisfaction of human needs, both for present and future generations. Sustainable agriculture 
conserves soil, water and plant resources and is non-degrading from an ecological point of view, technically appropriate, economically viable and socially satisfactory", the vision being towards sustainable agriculture where food is nutritious and accessible to the entire population and natural resources are managed in a rational manner that maintains ecosystem functions to support current and future human needs.

At the United Nations Conference on Environment and Development in Rio de Janeiro Earth Summit held in 1992, being created the action plan with global implementation, Agenda 21 and The Commission on Sustainable Development. At this Summit it was emphasized that sustainable development is a new mode of development that supports human progress for the entire population in the long term.

Smith and Smithers (1993) present the sustainability of agriculture as a development which should be based on 3 actions:

1. ensuring all food needs through food sufficiency, especially in the future when population growth is expected and implicitly in demand for food, sustainable development of agriculture is needed to cover all needs without compromising the resources needed for future generations.

2. the impact of agriculture on the environment is high due to the extensive exploitation of the land, but also intensive where the degree of use of chemicals is high and through the irrational use of natural resources, so the sustainable agriculture focus is on environmental stewardship.

3. sustainability also involves the harmonious development of the economy and the rural community because agriculture represents a large part of rural activity, so the socio-economic concerns must be considered.

Agribusiness includes the business activities realized from seed to farm to fork, is a major sector important sector of the global economy that has a major impact on the development of the rural economy, while ensuring the permanent access of the population to safety and security food. It covers the entire agrofood chain, from inputs to production, processing, and distribution to final consumer. (Conway \& Barbier, 1990). After the green revolution: Sustainable agriculture for development. In order to be sustainable, agribusiness must ensure, simultaneously, economic viability, environmental protection and social well-being and social cohesion, thus agriculture contributes to the four pillars defined by FAO to ensure food security: food availability, access to food, use and stability (Weingärtner, 2010). It is important for agribusiness to be managed in a way that is eco-friendly and socio-economically responsible in long term, sustainable.

A sustainable food system is the one that ensures the entire food safety and security for the population, so as not to compromise the socio-economic and environmental resources that generate the food security and the nutrition needed for future generations. (Food and Agriculture Organization, 2014a). The development of agrobusiness implies challenges for all actors in the chain, but the approach to the sustainability of agriculture must take into account a number of factors, such as the importance of agriculture in national economies, the degree of industrialization of agricultural production, the constraints determined by the availability of agricultural resources and the needs of the population and this sector has an important contribution in supporting the rural economy and contributing to the balanced territorial development and inclusive business, so the socio-economic and environmental aspects must not be overlooked.

According Conway and Barbier (1990) sustainable agriculture is interpreted in 3 different ways that correspond to the 3 pillars of sustainable development:

1. Economists consider sustainability to be long-term agricultural efficiency.

2. Sociologists consider it to be a representation of the social and traditional values of humanity. 
3. Environmentalists see it as the key to guarantee enough food for all population through an environmentally responsible agricultural system

In 2015, the United Nations (UN) adopted Agenda 2030 for Sustainable Development, which includes 17 clear and concise objectives on Sustainable Global Development (SGD). Out of the 17 objectives, 2 objectives obviously include agriculture and have specific actions to improve them until 2030.

PICBE | 1086

„Zero hunger" is an objective that provides to eliminate hunger, ensure food security, improve nutrition, and promote sustainable agriculture. By 2030, the sustainable development of agriculture aims to double the agricultural productivity and income of small farmers and want to create opportunities with value added for agriculture sector and this objective wants to ensure sustainable agrofood production and the implementation of resilient farming practices that increase the production, contribute to the resilience of ecosystems and strengthen adaptability to climate change. European Union emphasizes organic farming in order to achieve this objective, each Member State having a target to be achieved in terms of share \% of organic farming area in the total agricultural area of the country (United Nations,2015).

„Responsible consumption and production” result in more conscious behaviour, including more efficient production with a sustainable management and activities that accentuate the ecosystem protection. This target encourages countries to improve their scientific and technological capacity to move towards more sustainable consumption and production where the activities can be successfully accomplished through knowledge transfer, mainly based on researchdevelopment-innovation (United Nations,2015).

\section{Methodology}

The methodology of this study is divided into a quantitative analysis, an economic modelling was used, starting from the current situation of the Romanian agribusiness where official data and statistics were presented and analysed and a qualitative analysis represented mainly by PEST-EL analysis of agriculture sector of Romania.

In order to determine the dependence relation between the variable "net investments in agriculture" and "the share of ecological agriculture in total agriculture" we used the simple linear regression model. In order to apply the simple linear regression, the program Eviews 10+, Student Version Lite was used. In constructing the simple linear regression model between the two variables, we used statistical analysis for an overview of the data. The simple linear regression model is represented by the function $y=a+b x+\varepsilon$, where $\mathrm{y}$ - is the dependent variable, $\mathrm{x}$ - is the independent variable, $\varepsilon=$ residual variable, $a$ and $b=$ estimated parameters using the data series used to define the two variables.

\section{Results and discussions}

Issues related to food production, agricultural development policies and food security must dominate the strategies of development of the agricultural sector, especially its sustainable development. Agriculture is an important sector in Romania, especially in the rural area and given the economic diversification that has taken place in the last decades and the emergence and growth of other sectors, the agricultural sector remains the main activity sector in the rural economy and agriculture is too important for the economic and social well-being of the economy and should not be allowed to fall into decline. 


\section{The current situation of the Romanian agriculture sector}

Based on empirical analyses of the information, we present the current situation of agribusiness in Romania. Agriculture is an important sector of the Romanian economy and the basic activity in the Romanian rural area, especially from the perspective of the subsistence characteristics that agriculture has in the Romanian rural households.

According to the official statistical data provided by the National Institute of Statistics, the

PICBE $\mid 1087$ Gross Domestic Product of Romania increased by 4.1\% in 2018 compared to 2017, the largest contribution being that of population consumption. Agriculture, forestry, and fisheries have accumulated an increase of $0.40 \%$ and a low influence by $4.4 \%$ in national GDP formation, but which registered a significant increase by $9.9 \%$ in the volume of economic activity. In recent years, agriculture is influenced by an economic imbalance that has impacted the prices of agrofood products, inflation which occurs due to the oscillation of agricultural production, consumer demand and the high volatility of prices of agri-food products, both of agricultural raw material and of finished products.

Briefly studying the Romanian agriculture sector from the point of view of the three pillars of sustainability, we find some less positive characteristics that affect the proper development of the agriculture, but which through a sustainable development can be improved, thus contributing to a significant improvement of the sector (Table 1).

Table 1. The main characteristics of the agricultural sector from Romania

\begin{tabular}{|c|c|c|}
\hline Social & Economic & Environment \\
\hline $\begin{array}{c}\text { Small income for rural } \\
\text { versus urban households }\end{array}$ & Lower yields & $\begin{array}{c}\text { Low share of organic } \\
\text { farming }\end{array}$ \\
\hline Many subsistence farms & Many small farms & GHG emissions \\
\hline $\begin{array}{c}\text { Low level of agricultural } \\
\text { education }\end{array}$ & $\begin{array}{c}\text { Difficulties on the } \\
\text { agrofood supply chain } \\
\text { (processing, storage, } \\
\text { transport) }\end{array}$ & $\begin{array}{c}\text { Extreme weather } \\
\text { (torrential rain and } \\
\text { drought) }\end{array}$ \\
\hline
\end{tabular}

Source: Authors' own research results.

The rural population which represented $46 \%$ from total population in 2018 generally has lower incomes than the urban population because employment in agriculture predominates in the occupational structure and incomes in non-performing agriculture are low. Many of the workers from agriculture are members of subsistence farms and agricultural income is the most important source of income for rural households, being equivalent to the consumption of agrofood products from their own resources. The small farms have a lower yield of production and they stagnate due to difficulties on the agrofood supply chain and because of the lack of information, the level of agricultural education being a low one due to the lack of attractiveness of this field for young people. In Romania, traditional agriculture predominates, being one of the extensive types that contributes to a great extent to the creation of greenhouse gas emissions, this aspect being influenced by the climate change which has a harmful effect on agriculture. To all these we add the small share of Romanian organic area from the total agricultural area, only $2 \%$, which in a greater value would greatly help the socio-economic development and improve the agroecological characteristics, allowing sustainable development of agriculture. 


\section{PEST-EL analysis of agriculture sector of Romania}

In order to determine the situation facing the Romanian agricultural sector, we performed a qualitative analysis PEST-EL of agriculture sector of Romania which highlighted the main influential factors for agricultural development.

Political - aspects like national and EU legislation, there is strict legislation especially regarding the use of pesticides, genetically modified organisms, food safety, traceability, organic certified farming, traditional products certified at EU level and trade regulation. Agrarian reforms and national development plans must be respected and implemented well for the development of agricultural sector.

Economical - that includes farmer's income and taxes such as VAT which differs depending on the type of agrofood product - conventional, eco, traditional - inflation rates and customs duties, also mentioning contingents for extra-Community trade. Regional economic competitiveness is an important aspect that is analysed at EU level with the purpose of improving it to reduce regional disparities. The cost of labour force is an important economic indicator because a very large share of people from the rural area work in agriculture, but most of them work as day labourers, and due to this aspect legal issues have been realized for the evidence and for the appropriate payment. of them as well as to cover the main social contributions to the state budget. The market for the sale of agrofood products is still based on the traditional market and on the direct trade from the farm gate, directly from producers which doesn't have a legal entity, these modalities being less controlled from a fiscal point of view.

Social - the tradition of small farmers for subsistence and semi-subsistence agriculture influences the development of the sector, their spirit of owning property leads to landslides and lack of associative structures. Also, in the agricultural field, most are old people and the young ones lack the agricultural education and are no longer attracted to this field. In recent years, there has been an increase in ethical consumerism regarding the choice of Romanian consumers of organic or national products with an impact on the local community. Food security and the constant access of the population to food is an aspect that must always be taken into account because it directly influences the society, at present it is achieved through the consumption of food produced in one's own household for those in the rural area.

Technical - agriculture in Romania is suffering due to the lack of technological infrastructure, especially in the processing and storage stages and most agricultural machines. The degree of technical endowment is diminished, like tractors that are more than 30 years old and have low productivity using plenty of fuel. The irrigation system is a deficient one with old installations, a small agricultural area of only $2 \%$ being irrigated, but it begins to develop. The research, development and innovation activity are in progress of improvement after a long period in which the Romanian research in agriculture was advanced.

Environmental - the aspects related to environmental protection have increased and agriculture has a big contribution to: the emissions of greenhouse gases, agricultural waste as well as the appearance of losses during the supply chain, the clearing of forests to transform the land into the agricultural area, pollution of soil and water by irrational use of chemicals. An agricultural system with low-carbon impact on the environment is that of organic farming, which represents only $2 \%$ of the total agricultural area of Romania, but which is under development and drive to responsible consumption and production system. In present, the focus is on the protection of the environment and natural resources, so for the development of the agricultural sector must consider agricultural activities and the agrofood supply chain with a reduced impact on the environment. 
Legal - laws regarding the regulation of the Romanian agricultural sector, of the products and the market, certified by manufacturers, regulations regarding producer groups which must be respected precisely.

\section{Analysis of the agribusiness in Romania}

The main process that took place after 1989 was the retrocession of agricultural farms which were

PICBE | 1089 collectivized during the communist period and coming into state ownership, the reorganization of the management structures especially at the county level and the privatization of the state-owned agribusiness, increasing the number of private commercial companies that had as object of agricultural activity (Figure 1).

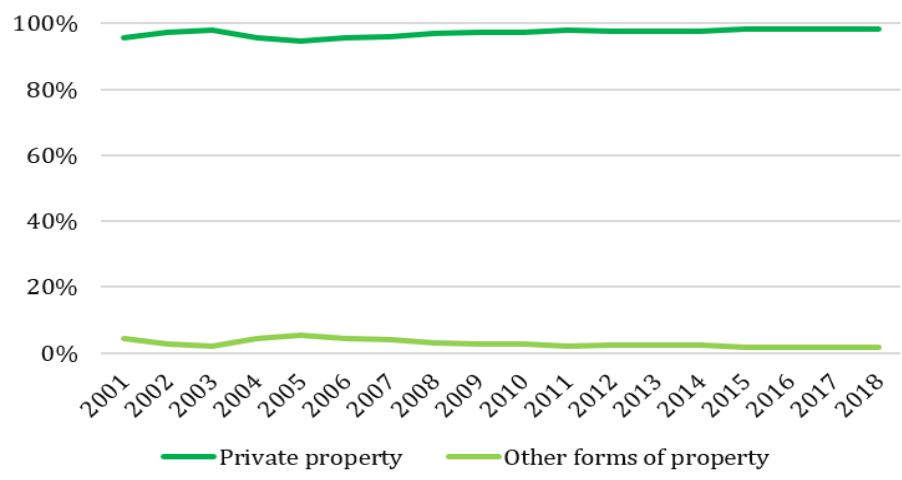

Figure 1. Share by type of agricultural property

Source: Romanian National Institute of Statistic.

In the last 18 year, the major direction of action for the formation of the new agricultural structure is the privatization, which means over $90 \%$ from total property in agriculture sector and this essentially determines the property and the agricultural exploitation, and which leads to the organization of the production in correlation with the market demand. The public property is represented by experimental and scientific surface which are under control of ministry or agronomy universities.

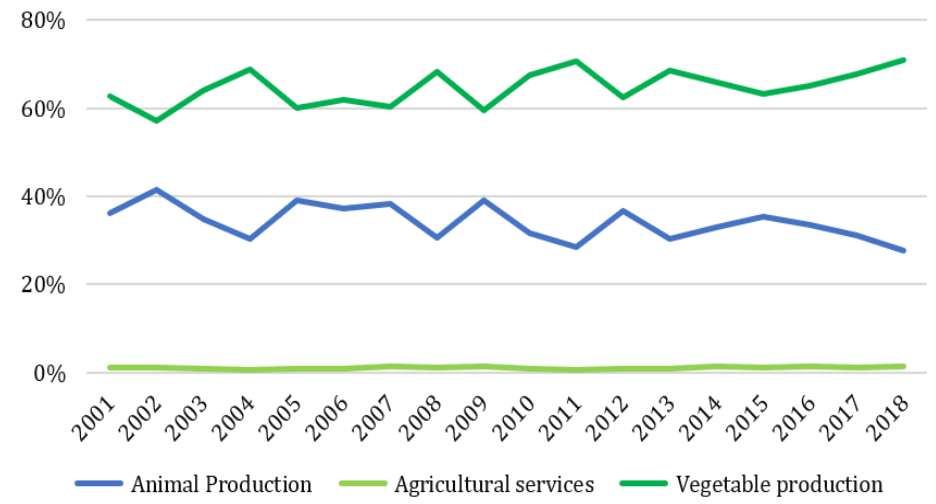

Figure 2. Share in production value by type of agricultural activities

Source: Romanian National Institute of Statistic.

In figure number 2, there is the evolution of agricultural activities, the main being the vegetable production where Romania has succeeded especially in cereal production, first place for 
corn production in 2018 in EU. The vegetable production is a various sector, including important production of fresh vegetables, mostly being produced in open space or in plastic greenhouse, some issues with fruits area because the trees are old and very sensitive at the extreme weather with few investments made on protection again ice or in variety which is adaptable to current natural condition and with intensive production of cereal with important materials raw which contribute to international commercial trade because mostly are exported, not only in the EU countries.

PICBE $\mid 1090$

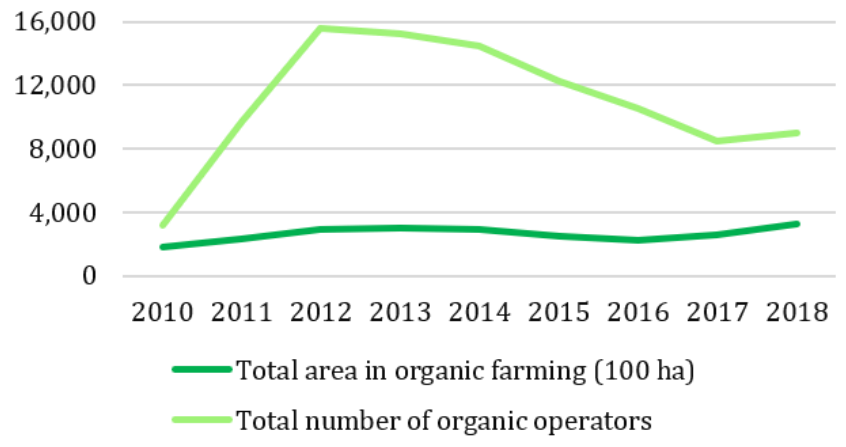

Figure 3. Share in production value by type of agricultural activities

Source: Ministry of Agriculture and Rural Development.

Organic farming is in a development process in Romania, the number of organic operators increased in 2018 versus 2017, but it is far from the number reached in 2015, over 15,000 operators registered and also the area is in progression, having a share of $2.2 \%$ from the total agricultural area from Romania (Figure 3). Organic farmers have the largest share of the total number of organic operators, the processors being in a small number. In present, organic farming has only $2 \%$ market share in the national sales, being representative by retail.

The current situation, however difficult it may seem, is not irreversible. Thus, considering the problems generated by the model of agriculture used so far in Romania, alternative food production systems have been developed, which are based on the principles of sustainability and which can be accessible in Romania through organic farming, conversion of vegetable and animal production from traditional conventional agriculture to organic farming and integrated agrofood chain management that demonstrates the sustainability of the products through the certificates specific to sustainable agriculture.

\section{Descriptive analyses}

Analysing the data from the table 2, it can be noted that the smallest value of the share of organic farming in the total agricultural area was $0.7 \%$, the maximum value was registered in 2018 with a weight of 2.43 and the average value recorded per during the analysed period it is $1.54 \%$. Regarding the net investments in agriculture, we find an average value per year of 3644.4 mil. RON, the minimum being reached in 2005 with a value of only 1502.3 mil. RON and the maximum value were reached in the year 2017, 5878.2 mil. RON.

Table 2. Database for descriptive statistics analyses 


\begin{tabular}{|c|c|c|c|c|c|}
\hline Years & $\begin{array}{c}\text { Share \% } \\
\text { organic } \\
\text { agriculture }\end{array}$ & $\begin{array}{c}\text { Net investments } \\
\text { in agriculture } \\
\text { (millions RON) }\end{array}$ & Years & $\begin{array}{c}\text { Share \% } \\
\text { organic } \\
\text { agriculture }\end{array}$ & $\begin{array}{c}\text { Net investments } \\
\text { in agriculture } \\
\text { (millions RON) }\end{array}$ \\
\hline 2005 & 0.7 & 1502.3 & 2012 & 2.1 & 3371.7 \\
\hline 2006 & 0.8 & 1954.9 & 2013 & 2.06 & 4257.3 \\
\hline 2007 & 1 & 2192.2 & 2014 & 2.09 & 4391 \\
\hline 2008 & 1 & 3393.3 & 2015 & 1.77 & 5333.5 \\
\hline 2009 & 1.2 & 2919.5 & 2016 & 1.67 & 4371.3 \\
\hline 2010 & 1.3 & 2659.8 & 2017 & 1.93 & 5878.2 \\
\hline 2011 & 1.6 & 3285.1 & 2018 & 2.43 & 5511.5 \\
\hline
\end{tabular}

Source: Romanian National Institute of Statistic and Eurostat.

For a more coherent interpretation of the two variables used in the simple linear regression, the logarithm of the variable "Net investments in agriculture" was used.

Following the test of the normality of each variable, as a result of the results obtained by Skewness, Kurtosis, Jarque-Bera and Probability, a normal distribution is found in both cases (Figure 4).

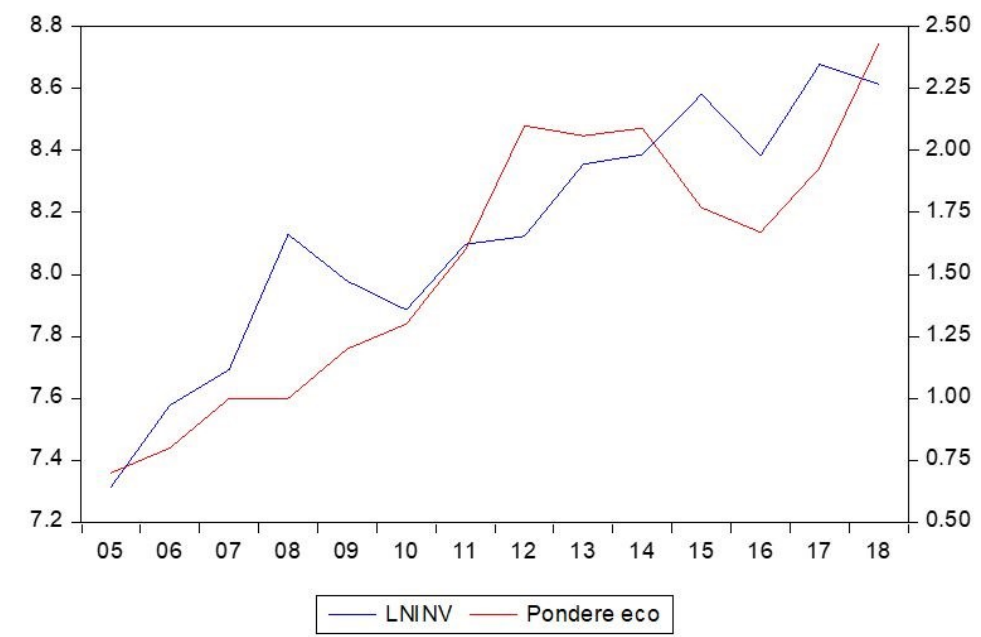

Figure 4. Distribution of variables

Source: Authors' own research results.

By analysing the database at the group level, we find a normal distribution, thus a new hypothesis is confirmed.

Using Unit Root Test, we notice that both each variable and group are stationary with a probability of $99 \%$ at LEVEL and the introduction of Trend and Intercept into the equation (Table $3)$.

Table 3. Steadiness of data taken at group level 


\begin{tabular}{|c|c|c|c|c|}
\hline Method & Statistic & Prob. ${ }^{* *}$ & $\begin{array}{c}\text { Cross- } \\
\text { sections }\end{array}$ & Obs \\
\hline \multicolumn{5}{|c|}{ Null: Unit root (assumes common unit root process) } \\
\hline Levin, Lin \& Chu $t^{*}$ & -2.00701 & 0.0224 & 2 & 25 \\
\hline Breitung t-stat & -1.95520 & 0.0253 & 2 & 23 \\
\hline
\end{tabular}

PICBE | 1092

Analysing the relationship at group level between the two variables, one can draw the conclusion that there is a close agreement between them (Table 4).

Table 4. The correlation matrix of the variables

\begin{tabular}{l|rr}
\hline \hline $\begin{array}{c}\text { Correlation } \\
\text { Probability }\end{array}$ & & \\
\hline LNINVEST & 1.000000 & \\
& ---- & \\
Organic share & 0.850276 & 1.000000 \\
& 0.0001 & $-\cdots$ \\
\hline \hline
\end{tabular}

Source: Authors' own research results.

Applying the linear model of the simple regression on the variables "the share of the ecological surface in the total agricultural area" and "the net investments in agriculture" it is shown that at an increase of $1 \%$ of the net investments in agriculture, the share of the ecological surfaces increases by $1.14 \%$. From the prism of the t-statistics test, it appears that the variable entered in the model is well chosen and produces effects on the endogenous variable. R-squared indicates the value of 0.72 , reflecting the fact that there is a strong influence of the exogenous variable on the endogenous variable. The probability of the F-statistics test is 0.000117 , less than 0.5 , confirming the validity of the model (Table 5).

Table 5. Results of the simple linear regression model

\begin{tabular}{lrlrr}
\multicolumn{1}{c}{ Variable } & Coefficient & Std. Error & t-Statistic & Prob. \\
\hline \hline \multicolumn{1}{c}{ LNINVEST } & 1.142968 & 0.204243 & 5.596124 & 0.0001 \\
\multicolumn{1}{c}{ C } & -7.744469 & 1.662180 & -4.659224 & 0.0006 \\
\hline \hline R-squared & 0.722970 & Mean dependent var & 1.546429 \\
Adjusted R-squared & 0.699884 & S.D. dependent var & 0.548643 \\
S.E. of regression & 0.300562 & Akaike info criterion & 0.565240 \\
Sum squared resid & 1.084052 & Schwarz criterion & 0.656534 \\
Log likelihood & -1.956680 & Hannan-Quinn criter. & 0.556789 \\
F-statistic & 31.31661 & Durbin-Watson stat & 1.327919 \\
Prob(F-statistic) & 0.000117 & &
\end{tabular}

Source: Authors' own research results.

In order to test the validity of the model, the residuals are nonlinear, homoscedastic, and normally distributed so that the model can be declared valid.

Studying the normality of the residuals it is found in figure 5 that in the case of the JarqueBera indicator, the $\mathrm{p}$-value registers a value greater than 0.05 , confirming that there is a normal distribution. 


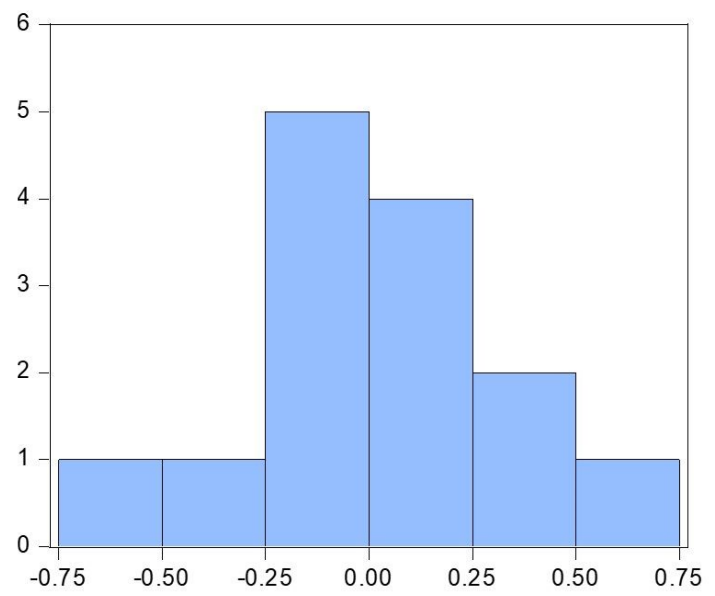

$\begin{array}{lr}\text { Series: Residuals } \\ \text { Sample 2005 } 2018 \\ \text { Observations } & 14 \\ & \\ \text { Mean } & 1.38 e-15 \\ \text { Median } & -0.008491 \\ \text { Maximum } & 0.559942 \\ \text { Minimum } & -0.547357 \\ \text { Std. Dev. } & 0.288771 \\ \text { Skewness } & 0.092223 \\ \text { Kurtosis } & 2.629601 \\ & \\ \text { Jarque-Bera } & 0.099876 \\ \text { Probability } & 0.951288\end{array}$

Figure 5. Testing the normality of residues

Source: Authors' own research results.

Using the White Test, according table 6, a test that represents another hypothesis of validation of the residuals and implicitly of the model, it is found that its probabilities register values greater than 0.05 , indicating the homoscedasticity of the residues.

Table 6. Homoscedasticity testing

\begin{tabular}{llll}
\hline \hline F-statistic & 0.919382 & Prob. F(2,11) & 0.4273 \\
Obs*R-squared & 2.005076 & Prob. Chi-Square(2) & 0.3669 \\
Scaled explained SS & 1.200297 & Prob. Chi-Square(2) & 0.5487 \\
\hline \hline
\end{tabular}

Source: Authors' own research results.

By testing the residual self-correlation, we notice in table 7 that Prob.Chi-square records the value 0.5302 , a value that is greater than 0.05 , confirming that the model is valid.

Table 7. Autocorrelation testing of residues / errors

$\begin{array}{llll}\text { F-statistic } & 0.498366 & \text { Prob. F }(2,10) & 0.6218 \\ \text { Obs*R-squared } & 1.268944 & \text { Prob. Chi-Square(2) } & 0.5302\end{array}$

Source: Authors' own research results.

\section{Strategic directions for developing agribusiness in the context of sustainable development of Romanian agriculture}

The conventional model of agricultural development emphasizes the increase of production and its intensification, but it is necessary to adapt an agricultural system that aims to achieve the dual objectives of increasing agricultural productivity and reducing the impact on the environment. Ensuring a sustainable increase in productivity will require several complementary activities. Sustainable administration of agrofood chain is a balanced combination of technologies, policies and activities, based on economic concepts and ecological considerations, in order to keep or increase agricultural production to the levels required to meet the wishes of global growth without degrading the environment, in order to achieve this sustainability, the innovation within the inclusive business is important. 
An important process to ensure the sustainability of agriculture is the integrated management of the agricultural company of all the stages of the supply chain that include quality reports, environment protection and hygiene controls (ISO 9001, HACCP). In the context of the sustainable development of the agricultural sector, a series of voluntary certification standards were set up which guarantees the control, quality and traceability of all agrofood products and the stages related to the agrofood supply chain, from seeds and cultivation to delivery of the product to the final consumer which prove that the agrofood production obtained respects the basic principles of sustainability and pays greater attention to them. The certification of agricultural products that guarantees the sustainability of the production must be considered within the strategies of development of agribusiness societies because it represents their vision for a long-term inclusive business.

Supply chains continue to create relationships more complex worldwide, the agrofood area especially, the use of sustainability is growing and shifting development of the company beyond its economic components to deal with social and environmental issues. Promoting low-carbon activities for supply chains is a challenging assignment for firms, but this allows an organization to achieve long-term economic viability. Increasing the efficiency of farming creates pathways to sustainable agrofood chain and systems, because efficiency contributes to profitability goals and to reduce the effects on natural resources by reducing resource losses. Reconnecting the food chain and approaching a sustainable strategy is a long-term path to progress, and constant improvement must be the driving force behind sustainable agriculture. According Sustainability Map which is managed by International Trade Centre we identify 39 standards which apply to sectors like Agriculture, Fish aquaculture and wild capture, Livestock and Processed Food only in Romania from a total of 170 standards worldwide. In table number 8 there are the 41 voluntary standards which have application now in Romania.

Table 8. Voluntary standard certificates for sustainability of agriculture sector in Romania

\begin{tabular}{|c|c|c|}
\hline Amfori BSCI & $\begin{array}{c}\text { Global Social Compliance } \\
\text { Programme - Environment } \\
\text { level } 3\end{array}$ & $\begin{array}{c}\text { International Sustainability and } \\
\text { Carbon Certification-Plus }\end{array}$ \\
\hline $\begin{array}{c}\text { BRC Global Standard for Food } \\
\text { Safety }\end{array}$ & $\begin{array}{l}\text { Global Social Compliance } \\
\text { Programme - Social Criteria }\end{array}$ & $\begin{array}{l}\text { OECD Guidelines for } \\
\text { Multinational Enterprises }\end{array}$ \\
\hline Donau Soja & GlobalGap Crops & RedCert \\
\hline EcoVadis & GlobalGap Floriculture & RedCert - EU \\
\hline EU Organic farming & $\begin{array}{c}\text { GlobalGap Risk Assessment of } \\
\text { Social Practice }\end{array}$ & SAI Platform \\
\hline Europe Soya & GMP+ Feed Certification & $\begin{array}{l}\text { SEDEX Global - Supplier } \\
\text { Ethical Data Exchange }\end{array}$ \\
\hline $\begin{array}{l}\text { European feed ingredients } \\
\text { Safety Certification }\end{array}$ & $\begin{array}{l}\text { Guide on Social Responsibility } \\
\text { for Chinese Int Contractors }\end{array}$ & $\begin{array}{c}\text { SEDEX Members Ethical } \\
\text { Trade Audit }\end{array}$ \\
\hline Fair Labour Association & $\begin{array}{c}\text { Initiative for Compliance and } \\
\text { Sustainability - Environmental } \\
\text { Criteria }\end{array}$ & $\begin{array}{l}\text { Social Accountability } \\
\text { International }\end{array}$ \\
\hline FEFAC Soy Sourcing & $\begin{array}{l}\text { Initiative for Compliance and } \\
\text { Sustainability - Social Criteria }\end{array}$ & $\begin{array}{l}\text { Sustainability Assessment of } \\
\text { Food and Agriculture systems }\end{array}$ \\
\hline $\begin{array}{l}\text { Food Safety System } \\
\text { Certification } 22000\end{array}$ & $\begin{array}{l}\text { International Featured } \\
\text { Standards - Food }\end{array}$ & UN Global Compact \\
\hline
\end{tabular}




\begin{tabular}{|c|c|c|}
\hline $\begin{array}{l}\text { Forest Stewardship Council - } \\
\text { Chain of Custody }\end{array}$ & $\begin{array}{c}\text { International Federation of } \\
\text { Organic Agriculture } \\
\text { Movements Standard }\end{array}$ & $\begin{array}{l}\text { Unilever Sustainability } \\
\text { Agriculture Code }\end{array}$ \\
\hline $\begin{array}{l}\text { Forest Stewardship Council - } \\
\text { Forest Management }\end{array}$ & $\begin{array}{c}\text { International Labour } \\
\text { Organization - Labour } \\
\text { standards }\end{array}$ & $\begin{array}{l}\text { United Nations Economic } \\
\text { Commission for Europe - } \\
\text { Standard FFV-50 Apples }\end{array}$ \\
\hline Global Reporting Initiative & $\begin{array}{l}\text { International Sustainability and } \\
\text { Carbon Certification-EU }\end{array}$ & $\begin{array}{c}\text { United States Department of } \\
\text { Agriculture - National Organic } \\
\text { Program }\end{array}$ \\
\hline $\begin{array}{c}\text { Global Social Compliance } \\
\text { Programme - Environment } \\
\text { level } 2\end{array}$ & & $\begin{array}{l}\text { World Fair Trade Organization } \\
\text { - Guarantee System }\end{array}$ \\
\hline
\end{tabular}

PICBE | 1095

Source: Sustainabilitymap.org.

In Romania, the EU Organic farming with 9008 operators registered in 2018 and Global Gap for crops are among the most recognized and most used by Romanian producers.

The central and strategic role played by organic farming in rural development is the key sector for economic growth, raising the standard of living, reducing poverty, and increasing food security. For a sustainable development of the agricultural sector, the main objective is to increase and support the organic agricultural production thought Eu Organic Farming standards for an abundant amount of safe, nutritious foods, ultimately resulting in high quality food. Organic farming develops its full potential as a sustainable food production strategy, faced with new challenges related to productivity, food safety and security, climate change and the rational use of natural resources.

Global Gap and EU Organic farming certification ensure the traceability of all the activities carried out for the realization of the agrofood product that certifies the food safety offered by the consumption of the product. With the help of technologies, an innovative label is created, the QR code that show the customer the process through the chosen product passed, all the information being transparent and establishing a reliable relationship between the producer and the consumer. The continuous growth of certification of agrofood products over the last few years reflects a demand among consumers, as well as producers to meet the common social and environmental concerns and the production and trade of certified products with a recognized standard for the offered sustainability allow to produce and sell in a way that ensures security food for consumers, rationalization, efficiency and sustainability of natural resources. These certifications bring added value of agrofood product being a competitive advantage for the producers and a benefit for the consumer creating an inclusive agribusiness.

\section{Conclusion}

The agricultural sector in Romania is in a good position to contribute to achieving the objectives regarding a smart, sustainable, and inclusive economy, which will allow to reach high levels of employment, productivity and increasing social cohesion. In fact, this sector is ideally positioned to contribute positively to the social, economic and environmental aspects relevant to the sustainable development of agriculture. Investing in agriculture is one in every of the handiest strategies for reducing hunger and poverty and generating economic growth, so responsible investment is a key aspect for the sustainable development.

Due to the fact that the notions of sustainability and organic products have taken a late approach (their importance is constantly growing), there are a few limitations of this research, the 
data series is short, both nationally and globally, it is recommended to retest the model in time, with the development of the database of this relatively new domain. Following the application of the simple linear regression on the variables "the share of the organic area in total agricultural area" and "the net investments in agriculture" it results that at an increase of 1 percentage point of the net investments in agriculture, the weight of the ecological surfaces increases by 1.14 percentage points.

In order to ensure sustainable development of the agricultural sector, ensuring the sustainability of productive agricultural systems, this sector is a priority and needs to be taken into account in satisfying the demand for food and providing stable and sustainable food that is safe with high quality products at affordable prices for the entire population. The present challenge of the organic farming sector is to ensure a constant increase of supply, but especially of the demand, through a consolidated agrofood chain maintaining the consumer confidence, being important to guarantee the credibility of the sector and the added value needs to be constituted in a long-term perspective that contributes to sustainability of farming.

The development of agriculture must aim at ensuring a safe and healthy quantity of food, now and in the future, especially in the face of challenges such as climate change and population growth. Plans and initiatives in the field of agricultural development, together with national policies for sustainable development, as well as commercial policies, should be developed, implemented and maintained in order to achieve economic growth and the well-being of citizens.

\section{References}

Conway, G.R., \& Barbier, E.B. (1990). After the green revolution: Sustainable agriculture for development. Earthscan.

Folke, C., Carpenter, S., Elmqvist, T., Gunderson, L., Holling, C.S, \& Walker, B. (2002). Resilience and Sustainable Development: Building Adaptive Capacity in a World of Transformations. AMBIO: A Journal of the Human Environment, 31(5), 437-440.

Food and Agriculture Organization (1988). The state of food and agriculture 1987-88. Retrieved from http://www.fao.org/3/a-ap667e.pdf.

Food and Agriculture Organization - HLPE (2014a). Food losses and waste in the context of sustainable food systems. Retrieved from http://www.fao.org/3/a-i3901e.pdf.

International Trade Centre . Sustainability standards. Retrieved from https://sustainabilitymap.org/standards?q=eyJzZWxlY3R1ZENsaWVudCI6Ik5PIEFGRk1 MSUFUSU9OIiwicHJvZHVjaW5nQ291bnRyeSI6W3sibmFtZSI6IlJvbWFuaWEiLCJyZ Wdpb24iOmZhbHNlfV19.

Ministry of Agriculture and Rural Development (??)Organic farming. Retrieved from https://www.madr.ro/en/organic-farming.html.

Pjanic, M., Vukovic, B., \& Mijic, K. (2018). Analysis of the market concentration of agricultural enterprises in AP Vojvodina. Strategic Management, 23(4), 40-45.

Romanian National Institute of Statistic (??).Statistics data.Retrieved from http://statistici.insse.ro:8077/tempo-online/\#/pages/tables/insse-table.

Smith, B., \& Smithers, J., (1993).Sustainable Agriculture: Interpretations, Analyses and Prospects. Canadian Journal of Regional Science. 16.

Soubbotina, T., (2004). Beyond Economic Growth. An Introduction to Sustainable Development., The World Bank Washington, D.C. 
Tomislav, K. (2018). The Concept of Sustainable Development: From its Beginning to the Contemporary Issues. Zagreb International Review of Economics and Business, 21(1), 6794.

United Nations (1973). Report of the United Nations conference on the human environment.

Retrieved from

https://www.un.org/ga/search/view_doc.asp?symbol=A/CONF.48/14/REV.1.

PICBE | 1097

United Nations (1993). Report of the United Nations Conference on Environment and

Development Volume I. Retrieved from

https://www.un.org/ga/search/view_doc.asp?symbol=A/CONF.151/26/Rev.1\%20(Vol.\%2 $0 \mathrm{I}) \&$ Lang $=\mathrm{E}$.

United Nations (2015). Transforming our world: The 2030 agenda for sustainable development. Retrieved from

https://sustainabledevelopment.un.org/content/documents/21252030\%20Agenda\%20for\% 20Sustainable\%20Development\%20web.pdf.

Weingärtner, L. (2010). The concept of food and nutrition security. Achieving Food and Nutrition Security, 3, 21-52. 